\title{
FACTORS RELATED TO MOTOR DEVELOPMENTAL DELAY OF NEWBORNS
}

\author{
Andréa Januario da Silva ${ }^{1,2}$, Luiz Antônio Tavares Neves ${ }^{1,3}$, Jaqueline da Silva Frônio ${ }^{1,4}$, \\ Luiz Cláudio Ribeiro',
}

DOI: dx.doi.org/10.7322/jhdg.88970

\begin{abstract}
Introduction: Studies on the association between motor developmental delay and events observed during the neonatal period are performed after discharge. In such cases, the associations found may be interfered by factors occurring between discharge from the NICU and evaluation. Evaluate newborns before hospital discharge can prevent these effects. The purpose of this study is to identify factors related to motor developmental delay of newborns when being discharged from Neonatal Intensive Care Unit. The method chosen to carry out this investigation was a prospective cohort, populationbased and analytic-descriptive study, and 178 newborns were assessed through the Test of Infant Motor Performance. Binomial logistic regression has been developed for analyzing the associated factors. Among the results obtained, $58.4 \%$ of them were premature, $56.2 \%$ were low weight newborns and $59.0 \%$ were male. The participants were selected among those with the following characteristics: Birth Weight (BW) 2304.3 g, Gestational Age (GA) 35.33 weeks. Morbidity occurred in $23.6 \%$ of the participants and $34.8 \%$ showed changes in the motor performance $(64.7 \%$ in the ones below $1501 \mathrm{~g}$ and $27.8 \%$ in the ones above $1500 \mathrm{~g}$ ). Upon completion of the TIMP, it was possible to conclude that the factors associated with motor developmental delay in the binomial logistic regression were prematurity, seizures, being female.
\end{abstract}

Key words: child's health, child development, newborn, risk factors, public health.

\section{INTRODUCTION}

Systematic evaluation of motor changes and associated morbidities in neonates in the Neonatal Intensive Care Unit (NICU) may provide important information about neurodevelopmental outcomes ${ }^{1}$ and may accelerate the initiation of intervention and facilitate the future development of these children². The number of adverse morbidities in the peri- and neonatal periods increases the risk of delayed developmental changes between 18 and 24 months of corrected age $^{3}$. Studies demonstrate that newborns from the NICU, mainly the extremely preterm newborns, may have delay in their neuromotor and cognitive development due to their biological characteristics (such as gestational age and birth weight) ${ }^{4,5}$ or interventions and complications in the peri- and neonatal periods ${ }^{6-8}$. Identifying factors which may increase an infant's risk of delay would allow clinicians to focus on children with higher risk and would also allow the enforcement of preventive measures aiming at avoiding the occurrence of such factors.
Evaluations of the practices carried out in the maternal and infant units are widely discussed in developed countries. In developing countries, systematic evaluation is just beginning, and data is available through databases such as the Vermont Oxford Network and the Brazilian Net of Neonatal Research ${ }^{9}$.

Studies about the relationship between the delay in developmental motor and events observed during the neonatal period usually involve clinical assessments carried out after hospital discharge. In such cases, the links identified might suffer from the interference of factors that took place between discharge from the NICU and the assessment: socioeconomic and stimulation conditions. Assessing the newborns before hospital discharge may prevent these effects.

A development evaluation at the time of discharge from the NICU couldbe used by hospital service to evaluate the discharge conditions of its users and to improve services quality, preventing risk factors to motor development delay in newborns. The aim of this study is to verify the

1 Programa de Pós-Graduação em Saúde Coletiva, Faculdade de Medicina, Universidade Federal de Juiz de Fora, UFJF; Núcleo Interdisciplinar de Estudos do Desenvolvimento Infantil - NIEDI, Faculdade de Fisioterapia, UFJF; 3Núcleo de Assessoria, Treinamento e Estudos em Saúde - NATES, UFJF, Juiz de Fora, MG, Brasil.

2 Mestre em Saúde Coletiva (UFJF), Departamento de. Saúde Coletiva - Faculdade de Medicina-UFJF.

3 Doutor Saúde da Mulher e da Criança (IFF); Professor adjunto do Departamento de. Saúde Coletiva - Faculdade de Medicina-UFJF.

4 Doutora em Ciências Médicas pela Universidade Estadual de Campinas (UNICAMP); Professora Adjunta da Faculdade de Fisioterapia da Universidade Federal de Juiz de Fora (UFJF), Juiz de Fora, MG, Brasil.

5 Doutor em Demografia pela UFMG, Professor Associado do Departamento de Estatística do Instituto de Ciências Exatas da UFJF, Juiz de Fora, MG, Brasil.

Corresponding author: andreajanu@yahoo.com.br

Artigo baseado em dissertação de mestrado cujos resultados, discussão e resultados serão apresentados em forma de artigos sendo este um deles. Defesa em 2011. Instituição UFJF.

Suggested citation: Silva AJ et al. Factors related to motor developmental delay of newborns. 24(3): 320-327

Manuscript submitted Aug 18 2014, accepted for publication Nov 212014. 
factors related to motor developmental delay in newborns and infants at the time of discharge from the NICU.

\section{METHODS}

A prospective examination of public health system users in the NICU was made. This study is part of the Morbidity and Mortality Project in the NICU, which was approved by the Ethics in Research Committee.

Newborns admitted to the NICU and who were assisted by the Unique Health System (SUS) in 2009 were included in the study. Each family was enrolled in the study following completion of informed consent. All newborns who lived in the municipality and had a birth weight (BW) above $400 \mathrm{~g}$ and gestational age (GA) above 21 weeks were SUS users. They participated in the study and were followed until being discharged from the hospital. Newborns (NB) with congenital malformations, genetic syndromes, progressive diseases, orthopaedic changes requiring surgeries and/or immobilisations, peripheral nervous system lesions, or who had a corrected age below 34 weeks postgestational upon discharge from the NICU were excluded.

Data referring to the pre-, peri- and postneonatal period was collected according to the forms used by the Vermont Oxford Network (VON) ${ }^{10,11}$ and motor developmental delay was evaluated by the Test of Infant Motor Performance (TIMP) ${ }^{12}$ at discharge.

Either on the day or three days prior to NICU discharge, the NB and infants were evaluated using TIMP, version 5.1. The TIMP administrator was trained in the implementation of the test by its authors and were deemed reliable in its administration.

In order to be assessed as having acceptable consistency when using item descriptions for scoring the TIMP, the Infit Mean Square of administraters must be less than 1.3 . To be considered a reliable rater, fewer than $5 \%$ misfitting ratings are required. The evaluator had discrepancy rate of $4 / 148=2.7 \%$ and Infit Mean Square is 0.9.

The TIMP scoring reliability assessment uses Rasch analysis. The evaluation of newborns and infants was carried out without the examiner knowing the participants' gestational age. The application and interpretation of TIMP were according to what is recommended in its manual ${ }^{12}$ and in articles about its use ${ }^{13-14}$. The classification of the participant's performance was made using the normative pattern of the test by age, which considers four categories: normal, light delay $(-0.5$ standard deviation (SD)), moderate (-1SD) and high $(-2 S D)^{12}$. A cut-off point of -1DP was used to classify motor development delay.

Studies indicate that showing altered motor developmental delay in TIMP increases the chances of development changes at subsequent ages. Campbell et al. ${ }^{16}$ demonstrated that the cut-off of 1 SD of TIMP was the one criterion which enables the highest percentile of correct classifications of motor performance at 6 and 12 months of age, $84 \%$ and $88 \%$ respectively. Kolobeet al. ${ }^{15}$ verified approximately $80 \%$ of correct classifications of TIMP for motor performance in the Peabody Developmental Motor Scales at preschool age. Flegel and Kolobe also demonstrated appropriate predictive values of TIMP at school age, with the same cut-off, and observed $74 \%$ of correct classifications in relation to performance in the Bruininks-Oseretsky Test of Motor Proficiency (BOTMP). This cut-off ( $-1 \mathrm{SD})$ therefore seems to be a good parameter of neo- and post-neonatal screening, and for this reason it was used in the present study for the classification of motor developmental delay.

Data was stored and analysed using the software Statistical Package for Social Science (SPSS) version 14.0 for Windows. All factors are categorical. To verify the significant association of factors to motor developmental delay, a chi-square or Fisher exact test was carried out. Variables which showed a $\mathrm{p}$-value lower than 0.1 were included in the binomial logistic regression analysis, to explore possible interactions, since there were no frequencies below five in the bivariate analysis. Those were considered significant at a p-value lower than $5 \%$ in all analyses.

In the analysis of risk factors for the occurrence of changes in motor performance, theoretical models of determination with hierarchical blocks of variables were constructed. Initially, a model for the block hierarchically closer to the event of interest (motor developmental delay) was set.

The significant variables remained in the following model when the variables of the second block were included. All significant variables of these two blocks remained in the following model, which included the variables of the third block and so on.

The blocks of variables followed the given hierarchical sequence: biological characteristics, perinatal and obstetric history, complications and intervention in the delivery room, respiratory complications and intervention in the NICU, neurological findings in the NICU, other complications and interventions in the NICU, survival state and morbidity in the survivors (Table 1-3).

The following variables belonged to the blocks and were analysed, however they were not significantly associated with motor development: biological factors (birth weight, gestational age, gender), perinatal and obstetric history (prenatal care, more than five prenatal consultations, rupture of the membrane for a period equal or superior to 24hrs, maternal systemic arterial hypertension, chorioamnionitis, maternal diabetes, antenatal corticosteroids, antenatal corticosteroids from 24 to 33 weeks of gestation, multiple gestation), complications and interventions in the delivery room (type of delivery - caesarean, bradycardia before delivery, tachycardia before delivery, Apgar score at $5 \mathrm{~min}>3$, Apgar score at $5 \mathrm{~min}<7$, initial resuscitation with $\mathrm{O}_{2}$, resuscitation with facial mask, initial resuscitation with oro tracheal tube, resuscitation with epinephrine, compression cardiac resuscitation, assisted ventilation until the 10 th minute of life, meconium aspiration syndrome, 
Table 1: Percentual frequency of motor developmental delay by biological characteristics, obstetric and perinatal history, complications and interventions in the delivery room

\begin{tabular}{|c|c|c|c|c|c|c|c|c|c|}
\hline & & & & & 1500 & g Birth & & 1500 & g Birth \\
\hline & & tal pop & oulation & & Wei & ight & & Wei & ight \\
\hline & & Altered & TIMP & & Iterec & d TIMP & & terec & d TIMP \\
\hline & $\mathbf{n}$ & $\%$ & p-value & $\mathbf{n}$ & $\%$ & p-value & $\mathbf{n}$ & $\%$ & p-value \\
\hline Biologicalcharacteristics & & & & & & & & & \\
\hline BirthWeight & & & 0.001 & & & - & & & - \\
\hline$>2501 \mathrm{~g}$ & 19 & 24.4 & & - & - & & - & - & \\
\hline $1501-2500 \mathrm{~g}$ & 21 & 31.8 & & - & - & & - & - & \\
\hline $1001-1500 \mathrm{~g}$ & 15 & 62.5 & & - & - & & - & - & \\
\hline$<1000 \mathrm{~g}$ & 7 & 70.0 & & - & - & & - & - & \\
\hline Gestational age & & & $<0.001$ & & & 0.012 & & & 0.040 \\
\hline$>37$ & 16 & 21.6 & & & & & 16 & 1.6 & \\
\hline $33-36$ & 22 & 32.4 & & 3 & 50.0 & & 19 & 30.6 & \\
\hline $30-32$ & 21 & 80.8 & & 16 & 88.9 & & & 2.5 & \\
\hline $27-29$ & 3 & 33.3 & & 3 & 33.3 & & & - & \\
\hline Sex ofinfant & & & $<0.001$ & & & 0.051 & & & 0.007 \\
\hline Female & 41 & 50.7 & & 19 & 78.9 & & 22 & 0.7 & \\
\hline Male & 33 & 23.8 & & 15 & 46.7 & & 18 & 20.0 & \\
\hline Obstetricand perinatal history & & & & & & & & & \\
\hline Prenatalcare** & & & $0.002 *$ & & & $273 *$ & & & $0.084 *$ \\
\hline no & 6 & 100.0 & & 4 & 100.0 & & & 00.0 & \\
\hline yes & 52 & 33.5 & & 15 & 62.5 & & 37 & 8.2 & \\
\hline Antenatalsteroids** & & & 0.032 & & & $0.212 *$ & & & 0.157 \\
\hline no & 36 & 30.5 & & 8 & 88.9 & & 28 & 25.7 & \\
\hline yes & 26 & 47.3 & & 14 & 58.3 & & 12 & 38.7 & \\
\hline $\begin{array}{l}\text { Complications and interventions in } \\
\text { delivery room }\end{array}$ & & & & & & & & & \\
\hline Bradycardia prior delivery** & & & $0.098 *$ & & & $0.512 *$ & & & $0.155^{*}$ \\
\hline no & 51 & 34.0 & & 16 & 59.3 & & 35 & 8.5 & \\
\hline yes & 5 & 71.4 & & 2 & 100.0 & & & 0.0 & \\
\hline Initialressuscitationoxygen** & & & 0.018 & & & $0.276 *$ & & & 0.053 \\
\hline no & 17 & 24.6 & & 4 & 100.0 & & 13 & 20.0 & \\
\hline yes & 45 & 42.1 & & 18 & 62.1 & & 27 & 34.6 & \\
\hline Initial ressuscitationfask mask vent** & & & 0.022 & & & $0.249 *$ & & & 0.020 \\
\hline no & 31 & 28.7 & & 10 & 83.3 & & 21 & 1.9 & \\
\hline yes & 31 & 45.6 & & 12 & 57.1 & & 19 & 0.4 & \\
\hline Assisted ventilation until the $10^{\circ} \mathrm{min} * *$ & & & 0.037 & & & $0.212 *$ & & & 0.340 \\
\hline no & 40 & 30.8 & & 8 & 88.9 & & 32 & 26.4 & \\
\hline yes & 22 & 47.8 & & 14 & 58.3 & & & 36.4 & \\
\hline Admission hypothermia** & & & 0.068 & & & $0.671 *$ & & & 0.463 \\
\hline no & 28 & 35.0 & & 5 & 55.6 & & 23 & 32.4 & \\
\hline yes & 20 & 52.6 & & 11 & 68.8 & & & 10.9 & \\
\hline
\end{tabular}

Legend: $*$ Fisher exact test; $* *$ it has missing cases; $\mathrm{p}$-value $=$ motor performance (altered or not) by specified characteristics $\mathrm{n}=$ absolut frenquency of motor developmental delay; $\%$ = relative frequency of motor developmental. 
Table 2: Percentual frequency of motor developmental delay by respiratory complications and interventions, neurologicalfindings

\begin{tabular}{|c|c|c|c|c|c|c|c|c|c|}
\hline & \multicolumn{3}{|c|}{$\begin{array}{l}\text { Total population } \\
\text { Altered TIMP }\end{array}$} & & $\begin{array}{r}1500 \mathrm{~g} \\
\text { Weig } \\
\text { Itered }\end{array}$ & $\begin{array}{l}\text { Birth } \\
\text { ht } \\
\text { TIMP }\end{array}$ & \multicolumn{3}{|c|}{$\begin{array}{c}>1500 \mathrm{~g} \text { Birth } \\
\text { Weight } \\
\text { Altered TIMP }\end{array}$} \\
\hline & $\mathbf{n}$ & $\%$ & p-value & $\mathbf{n}$ & $\% \mathrm{p}$ & -value & $\mathbf{n}$ & $\%$ & p-value \\
\hline \multicolumn{10}{|l|}{$\begin{array}{l}\text { Respiratory complications and } \\
\text { interventions }\end{array}$} \\
\hline Respiratorysupport $\mathrm{O}^{2}$ & & & 0.003 & & & $0.353 *$ & & & 0.026 \\
\hline no & 2 & 8.3 & & 0 & 0 & & 2 & 8.7 & \\
\hline yes & 60 & 39.0 & & 22 & 66.7 & & 38 & 31.4 & \\
\hline Nasal CPAP & & & 0.001 & & & $0.118^{*}$ & & & 0.046 \\
\hline no & 13 & 19.1 & & 0 & 0 & & 13 & 19.7 & \\
\hline yes & 49 & 44.5 & & 22 & 68.8 & & 27 & 34.6 & \\
\hline Respiratorysupport - ventcon*** & & & 0.002 & & $1 *$ & & & & 0.102 \\
\hline no & 20 & 23.3 & & 1 & 50.0 & & 19 & 22.6 & \\
\hline yes & 42 & 45.7 & & 21 & 65.6 & & 21 & 35.0 & \\
\hline Mechanical Ventilation & & & 0.004 & & & 0.425 & & & 0.199 \\
\hline no & 20 & 23.3 & & 1 & 50.0 & & 19 & 22.6 & \\
\hline$<4$ hs & 0 & 0 & & - & - & & 0 & 0 & \\
\hline $4-24$ hs & 2 & 25.0 & & 1 & 33.3 & & 1 & 20.0 & \\
\hline$>24$ hs & 40 & 48.8 & & 20 & 69.0 & & 20 & 37.7 & \\
\hline Surfactant & & & $<0.001$ & & 0.912 & & & & 0.068 \\
\hline no & 33 & 26.6 & & 4 & 66.7 & & 29 & 24.6 & \\
\hline yes & 29 & 53.7 & & 18 & 64.3 & & 11 & 42.3 & \\
\hline Steroids for Chronic lung disease & & & $<0.001 *$ & & $.252 *$ & & & & $0.020 *$ \\
\hline no & 50 & 30.5 & & 13 & 56.5 & & 37 & 26.2 & \\
\hline yes & 12 & 85.7 & & 9 & 81.8 & & 3 & 100.0 & \\
\hline Respiratory distress syndrome & & & 0.012 & & & $0.635^{*}$ & & & 0.102 \\
\hline no & 23 & 25.8 & & 4 & 80.0 & & 19 & 22.6 & \\
\hline yes & 39 & 43.8 & & 18 & 62.1 & & 21 & 35.0 & \\
\hline Chroniclung disease & & & $<0.001$ & & & 0.236 & & & $0.141 *$ \\
\hline no & 45 & 29.6 & & 10 & 55.6 & & 35 & 26.1 & \\
\hline yes & 17 & 65.4 & & 12 & 75.0 & & 5 & 50.0 & \\
\hline \multicolumn{10}{|l|}{ Neurologicalfindings } \\
\hline Seizures** & & & $<0.001$ & & & $0.378 *$ & & & $0.003 *$ \\
\hline no & 47 & 29.9 & & 16 & 59.3 & & 30 & 23.6 & \\
\hline yes & 15 & 71.4 & & 6 & 85.7 & & 9 & 64.3 & \\
\hline Ventriculo megaly** & & & $<0.001$ & & & $0.223 *$ & & & $0.002 *$ \\
\hline no & 28 & 35.4 & & 15 & 57.7 & & 13 & 24.5 & \\
\hline yes & 11 & 91.7 & & 6 & 85.7 & & & 100.0 & \\
\hline Peri-Intraventricular Hemorrhage grau $>3 * *$ & & & $0.008 *$ & & & $0.626 *$ & & & $0.023 *$ \\
\hline no & 30 & 37.0 & & 16 & 59.3 & & 14 & 25.9 & \\
\hline yes & 7 & 87.5 & & 4 & 80.0 & & & 100.0 & \\
\hline Cystic Periventricular Leukomalacia** & & & $0.024 *$ & & & $1 *$ & & & $0.020 *$ \\
\hline no & 35 & 37.6 & & 20 & 62.5 & & 15 & 24.6 & \\
\hline yes & 4 & 100.0 & & & 100.0 & & & 100.0 & \\
\hline Alteration of the SNC** & & & 0.017 & & & 1 & & & $0.035 *$ \\
\hline no & 21 & 33.9 & & 10 & 62.5 & & 11 & 23.9 & \\
\hline yes & 17 & 60.7 & & 10 & 62,6 & & 7 & 58.3 & \\
\hline
\end{tabular}

Legend: *Fisher exact test; $* *$ it has missing cases; $\mathrm{p}$ - value $=$ motor performance (altered or not) by specified characteristics; $* * *$ Conventionalmechanicalventilation; $\mathrm{n}=$ absolutfrenquency of motor developmental delay; $\%=$ relative frequency of motor developmental delay in the TIMP. 
Table 3: Percentual frequency of motor developmental delay by other complications and interventions in the NICU and morbidity in the survivors

\begin{tabular}{|c|c|c|c|c|c|c|c|c|c|}
\hline \multirow[b]{2}{*}{$\begin{array}{l}\text { Other complications and interventions in } \\
\text { the NICU }\end{array}$} & \multicolumn{3}{|c|}{$\begin{array}{l}\text { Total population } \\
\text { Altered TIMP }\end{array}$} & \multicolumn{3}{|c|}{$\begin{array}{l}\quad \leq 1500 \mathrm{~g} \\
\text { BirthWeight } \\
\text { Altered TIMP }\end{array}$} & \multicolumn{3}{|c|}{$\begin{array}{c}>1500 \mathrm{~g} \text { Birth } \\
\text { Weight } \\
\text { Altered TIMP }\end{array}$} \\
\hline & $\mathbf{n}$ & $\%$ & p-value & $\mathbf{n}$ & $\%$ & -value & $\mathbf{n}$ & $\%$ & p-value \\
\hline Patentductusarteriosus & & & $0.051 *$ & & & $1^{*}$ & & & $0.480 *$ \\
\hline no & 55 & 32.9 & & 16 & 64.0 & & 39 & 27.5 & \\
\hline yes & 7 & 63.6 & & 6 & 66.7 & & 1 & 50.0 & \\
\hline Sepsis/meningitis late & & & 0.044 & & & $1 *$ & & & $0.190 *$ \\
\hline no & 51 & 32.3 & & 17 & 63.0 & & 34 & 26.0 & \\
\hline yes & 11 & 55.0 & & 5 & 71.4 & & 6 & 46.2 & \\
\hline \multicolumn{10}{|l|}{ Morbidity in thesurvivors } \\
\hline Comorbidity & & & $<0.001$ & & & $0.163 *$ & & & $0.068 *$ \\
\hline no & 37 & 26.8 & & 7 & 50.0 & & 30 & 24.6 & \\
\hline yes & 25 & 62.5 & & 15 & 75.0 & & 10 & 45.5 & \\
\hline Length of stay longer than 120 days & & & $0.008 *$ & & & $0.273^{*}$ & & & $0.187 *$ \\
\hline no & 56 & 32.7 & & 18 & 60.0 & & 38 & 27.0 & \\
\hline yes & 6 & 85.7 & & & 00.0 & & 2 & 66.7 & \\
\hline
\end{tabular}

Legend: *Fisher exact test; $\mathrm{p}$-value $=$ motor performance (altered or not) by specified characteristics; Comorbidity = the sum of: severe IVH (equal to IVH < 3), DPC, NEC, pneumothorax, late infection, PVL, length of stay longer than 120 days; $n=$ absolut frenquency of motor developmental delay; $\%=$ relative frequency of motor developmental delay in the TIMP

meconium aspiration, hypothermia on admission to the NICU), respiratory complications and interventions in the NICU (respiratory support with $\mathrm{O}_{2}$, continuous positive airway pressure (NCPAP), respiratory support - mechanical ventilation, time on mechanical ventilation, nitric oxide, surfactant (SURF), surfactant administered over two hours of life, corticosteroids for bronco pulmonary disease (BPD), respiratory distress syndrome (RDS), pneumothorax, pulmonary hypertension, chronic lung disease), neurological findings (hypoxic ischemic encephalopathy, seizures, seizures until $72 \mathrm{hs}$, ventriculomegaly, periintraventricular haemorrhage (IVH), IVH level e"3, peri-ventricular leukomalacia ( $P V L)$, alteration of the central nervous system (AltCNS)), other complications and interventions (Enteral diet d" 7 days, persistence of the ductusarteriosus, meningitis or encephalitis, early sepsis, late sepsis/meningitis, retinopathy of prematurity (ROP), ROP level e" 3, necrotizing enterocolitis, renal failure, syndrome of inappropriate antidiuretic hormone, disseminated intravascular coagulation, hepatic dysfunction, hyperbilirubinemia, cardiac dysfunction, toxoplasmosis-rubellasyphilis-cytomegalovirus-herpes simplex $(\mathrm{TORCH})$ ).

Bivariate analyses were also carried out for groups with weight below or equal to $1500 \mathrm{~g}$, and above $1500 \mathrm{~g}$, since motor development delay may be related to a number of factors in NB with significantly low weight. This subdivision was not used in the binomial logistic regression however, because of the instability generated in the models, due to low frequencies.

\section{RESULTS}

Two hundred and sixty NB were hospitalised in the NICU, which represents $4.5 \%$ of the live births in the city in the year 2009. Among those, 178 (69\% of the study population) satisfied the inclusion criteria of the present study, 58.4\% were premature, $56.2 \%$ were born with low weight and $59.0 \%$ were male. $13.5 \%$ of the newborns weighed between 1001 and $1500 \mathrm{~g}, 5.6 \%$ were below or equal to $1000 \mathrm{~g}$, and $20.2 \%$ were below 33 weeks of gestation ( $5.7 \%$ below 30 weeks). The NB showed an average birth weight of $2304 \mathrm{~g}$ (SD 802.9), an average gestational age of 35 weeks (SD 3.5) and they were evaluated by TIMP with corrected age of 38 weeks post gestational (SD 3.3), having an average TIMP score of 50 (SD 17.6).

Almost a quarter of the NB showed some of the morbidities, with a higher prevalence in NB with weight below or equal to $1500 \mathrm{~g}$. From the 178 participants who were assessed upon discharge from the NICU, 62 (34.8\%) had delayed motor performance (TIMP d" -1SD) (64.7\% in those below $1501 \mathrm{~g}$ and $27.8 \%$ in those above $1500 \mathrm{~g}$ ). This research showed that lower birth weight and gestational age led to a higher frequency of motor changes, reaching $66.7 \%$ in those below 33 weeks of GA and $70 \%$ in the infants with weight below 1001g. Tables 1 to 3 show the factors significantly associated with delayed motor performance in the bivariate analyses. Some of these factors were analysed in a smaller number of participants, due to the fact that it wasn't possible to find certain data in the records. 
Initially, the variables of biological characteristics were included in the regression models. They were removed one by one from the model, following an order of decreasing not significant $p$-values.

The final model is shown in Table 4. In this model, 175 cases were considered in the analyses, in which no data was missing. The results, according to the odds ratio, indicated that the chances of having delayed motor performance upon discharge from the NICU were $86 \%$ lower for children born at term than among those born at up to 32 weeks. Having a gestational age between 33 and 36 weeks reduced the chance of delayed motor performance by $76 \%$ when compared to those with a lower GA.

Table 4: Motor developmental delay in the TIMP by factors significantly associated (Binomial Logistic Regression)

$\begin{array}{lcccc} & \text { Sig. } & \text { OR } & \text { LI } & \text { UI } \\ \text { Gestacional age } & 0.000 & & 0.05 & 0.36 \\ \text { Gestacional age }(1)^{*} & 0.000 & 0.138 & 0.10 & 0.61 \\ \text { Gestacional age }(2)^{* *} & 0.003 & 0.242 & 1.32 & 5.50 \\ \text { Sex }(1)^{* * *} & 0.007 & 2.694 & 0.07 & 0.65 \\ \text { Seizures } & 0.006 & 0.215 & \end{array}$

Legend: OR = odds ratio; $\mathrm{LI}=$ lower limit; UI= upper limit (95.0\% C.I.);

* Reference was age 33 until 36 weeks; ${ }^{* *}$ reference: age $<32$ weeks; ${ }^{* * *}$ reference: female.

Newborns who did not have seizures were $78.5 \%$ less likely to have delayed motor development. Being female increased the chance of having delayed motor performance by $169 \%$ (Table 4). Analyses carried out separately by weight category indicated that associations between motor developmental delay and the factors considered in this study seem plausible.

Regression models were not run for these cases, however, because of instabilities observed in the odds ratios, due to small frequencies in the studied population.

\section{DISCUSSION}

Studies that assess motor performance are generally conducted after hospital discharge, which may cause interference of socioenvironmental factors. In contrast, this study observed factors associated when the high NICU (Neonatal Intensive Care Unit).

The verification of the factors associated with delayed motor development in newborns and infants at discharge from the NICU should be performed so that preventive measures can be taken avoinding, thus, the occurrence of these factors and the risk of changes that can negatively influence even into adulthood.

The individuals with lower BW and GA showed a higher prevalence of motor developmental delay. These results are similar to those reported in the literature, ${ }^{17,18}$ as the presence of abnormal movements at three months of age is associated with prematurity ${ }^{19}$.

Some alterations that can occur in the periand neonatal period are precocious and definitive; others can appear later. However, the interaction of these problems with environmental factors may boost the effects on neuromotor development. In spite of the fact that references supporting the previously mentioned evidence cannot be found in the literature, in this study, being female increased the chance of having delayed motor performance by more than $150 \%$.
The use of antenatal corticosteroids was negatively associated with motor performance, however, when considering only newborns between 24-33 weeks of gestational age, the results suggest that the corticosteroids were a protecting factor for those below $1501 \mathrm{~g}(\mathrm{p}=0.097)$ and a risk factor for those above $1500 \mathrm{~g}(p=0.069)$. The number of corticosteroids cycles administered was not controlled in this study, but the literature reports that multiple cycles may be associated with abnormalities in neurodevelopment ${ }^{20,21}$.

Newborns who needed resuscitation with oxygen, facial mask, or ventilator attendance until 10 minutes of age in the delivery room, or who suffered hypothermia in the delivery room, initial endotracheal tube, initial resuscitation, cardiac compression and epinephrine administration had a higher frequency of delayed motor performance. These findings suggest the following questions: did these lower weight newborns receive appropriate care in the delivery room? Were the best practices used? Perhaps more appropriately, had the mothers been given a proper prenatal consultation?

Higher odds of change were found in motor performance in all categories of breath support (oxygen, conventional mechanical ventilation, CPAP) which agrees with the findings of Nicholas et al. ${ }^{21}$. The same was found for respiratory complications and interventions (surfactant, corticosteroids for $B P D$, chronic lung disease and respiratory distress syndrome).

These findings should be interpreted with caution because, in some cases, they may not indicate that the intervention used is negative for motor performance, but that the need of such interventions indicates that the neonate had a more severe clinical frame. In the literature, this issue is controversial. Souza et al. ${ }^{22}$ compared the neurological assessment of preterm infants with and without BPD and found no statistically significant differences between groups, however other authors indicate strong evidence that respiratory changes are negatively associated with motor development.

The presence of at least one alteration of the central nervous system (periventricular 
leukomalacia, intraventricularhaemorrhage, ventriculomegaly) or of seizures was associated with delayed motor performance. Holcroft et al. ${ }^{25}$ investigated risk factors for neonatal neurological morbidities (IVH, seizures, hydrocephalus and PVL) in newborns with very low birth weight and observed that gestational age, birth weight and neonatal infection were strongly related to the higher frequency of these morbidities.

In this way, actions that seek the prevention of prematurity, low birth weight and neonatal infections may also impact the decrease in the prevalence of CNS changes and, consequently, of changes in motor performance. Mercier et al. ${ }^{3}$ reported leukomalacia, intraventricular haemorrhage and severe congenital malformations as the factors most associated with severe disability in infants from 18 to 24 months of age who were born with low birth weight.

Among the newborns and infants who showed morbidity (severe IVH, CLD 36 $<33$, Necrotizingenterocolitis (NEC), PNMTX, late infection, PVL, length of hospital stay longerthan 120 days), almost $60 \%$ had delayed motor performance. Following development up is important, even for those who do not show these morbidities, because changes in neuromotor development may still occur, indicating that changes in motor performance are not only associated with those causes.

Being of lower gestational age, having a history of seizures and being female were the factors that remained significantly associated with delay in motor performance after the application of regression models. So, the main measures to prevent changes in motor performance should be those to avoid the premature birth and also those that lower foetal distress and newborn complications that can lead to seizures.

Current studies indicate that motor performance changes in TIMP increase the chances of developmental changes at subsequent ages. Campbell et al. ${ }^{15}$ demonstrated that cutting -1 SD of TIMP was the criterion for the highest percentage of correct classifications of motor performance at 6 and 12 months of age, $84 \%$ and $88 \%$, respectively. Kolobe et al. ${ }^{15}$ found approximately $80 \%$ of correct classifications of TIMP for the motor performance according toPeabodyDevelopmental Motor Scales in preschool.

\section{REFERENCES}

1. Spittle AJ, Treyvaud K, Doyle LW, Roberts G, Lee $\mathrm{KJ}$, Inder $T E$, et al. Early emergence of behavior and social-emotional problems in very preterm infants. J Am Acad Child AdolescPsychiatry. 2009 Sep;48(9):909-18.

2. Santos RS, Araújo AP, Porto MA. Early diagnosis of abnormal development of preterm newborns: assessment instruments. J Pediatr (Rio J). 2008 Jul-Aug;84(4):289-99.

3. Mercier CE, Dunn MS, Ferrelli KR, Howard DB, Soll RF. Neurodevelopmental outcome of extremely low birth weight infants from the Vermont Oxford network: 1998-2003. Neonatology. 2010 Jun;97(4):329-38. Epub 2009 Nov 24.
Flegel and Kolobe ${ }^{15}$ also demonstrated adequate predictive values of TIMP, at schoolage, with the same cut-off point, and observed $74 \%$ of correct classifications in relation to performance in theBruininks-Oseretsky Test of Motor Proficiency (BOTMP). Therefore, this cut-off point ( $-1 \mathrm{SD})$ seems to be a good parameter of neo- and post-neonatal screening and, for this reason, it was used in the study for the classification of delayed motor performance.

Further studies of this nature are suggested, comparing the findings and also implementation of the evaluation of motor performance at discharge from the NICU. Furthermore, follow-up and reevaluation of this population is needed to calculate sensitivity, specificity, predictive values, and the accuracy of TIMP at discharge from the NICU, since TIMP, although not validated in Brazil, seems to be the best choice in this age range ${ }^{26-28}$.

The use of some secondary data in the survey of possible factors related to motor performance may represent a limitation of the study because the quality of the records cannot be ensured. Nevertheless, it was possible to make a consistent analysis of the data.

Some clinical conditions in the neonatal period can result in morbidity, or more frequent hospitalisations in childhood, which can generate significant economic and social impact through worker absenteeism in adulthood and/or the financial burden placed on the public health system, which deserves careful attention to investigation on global public health ${ }^{29,30}$. Interventions that contribute to improving the health of the foetus have a positive impact on birth outcomes, on health in the neonatal period and, even later, in adulthood.

In conclusion, the factors which increased the probability of delayed motor performance in the studied population were the following: prematurity, being female and having had seizures. The observed results showed a high prevalence of changes in motor performance upon discharge from the NICU, mainly among newborns with GA d" 32 weeks and/ or BW $d^{\prime \prime} 1500 \mathrm{~g}$. These findings demonstrate the need of further studies of the quality of peri- and neonatal care and reinforce the evidence that newborns egressing from the NICU should be involved in follow-up programmes.

4. Gargus RA, Vohr BR, Tyson JE, High P, Higgins $R D$, Wrage LA, et al. Unimpaired outcomes for extremely low birth weight infants at 18 to 22 months. Pediatrics. 2009 Jul;124(1):112-21.

5. Moster, D., Lie, R.T., \&Maskestad, T. Long-term medical and social consequences of preterm birth. The New England Journal of Medicine. 2008; 359: 262-273.

6. Peralta-Carcelen M, Moses M, Adams-Chapman I, Gantz M, Vohr BR. Stability of neuromotor outcomes at 18 and 30 months of age after extremely low birth weight status. Pediatrics. 2009 May;123(5): e887-95.

7. Tyson JE, Parikh NA, Langer J, Green C, Higgins RD. Intensive care for extreme prematuritymoving beyond gestational age. $N$ Engl J Med. 2008 Apr 17;358(16): 1672-81. 
8. Hintz SR, Kendrick DE, Vohr BR, Poole WK, Higgins RD. Community supports after surviving extremely low-birth-weight, extremely preterm birth: special outpatient services in early childhood. Arch PediatrAdolesc Med. 2008 Aug;162(8):748-55.

9. Barros FC, Diaz-Rossello JL. Redes multicêntricas e qualidade da atenção neonatal. J Pediatr (Rio J). 2004;80:254-6.

10. Vermont Oxford Network. Manual of operations for infants born in 2009: Release 13.2. 2009. $173 p$.

11. Vermont Oxford Network. Neonatal Encephalopathy Registry: Manual of operations. Version 3.3. 2009. 109p.

12. Campbell SK. The Test of Infant Motor Performance. Test User's Manual Version 2.0. Chigago; 2005. 37p.

13. Lekskulchai R, Cole J. Effect of a developmental program on motor performance in infants born preterm. Aust J Physiother. 2001;47(3):169-76.

14. Kolobe THA, Bulanda M, Susma I. Predicting motor outcome at preschool age for infants tested at $7,30,60$, and 90 days after term age using the Test of Infant Motor Performance. PhysTher. 2004:84(12):1144-56.

15. Campbell SK, Kolobe THA, Wright BD, Linacre JM. Validity of the Test of Infant Motor Performance for prediction of 6-, 9- and 12month scores on the Alberta Infant Motor Scale. Dev Med Child Neurol. 2002;44: 263-272.

16. Petrini JR, Dias T, McCormick MC, Massolo ML, Green NS, Escobar GJ. Increased risk of adverse neurological development for late preterm infants. J Pediatr. 2009 Feb;154(2):169-76.

17. Rugolo LMSS. Crescimento e desenvolvimento a longo prazo do prematuro extremo. J. pediatr. (Rio J.) 2005 mar.;81(1 supl):101-10.

18. Farel AM, Hooper SR, Teplin SW, Henry MM, Kraybill EN. Very-low-birthweight infants at seven years: an assessment of the health and neurodevelopmental risk conveyed by chronic lung disease. J Learn Disabil 1998; 31(2): 118-26.

19. Spinillo A, Viazzo F, Colleoni R, Chiara A, Maria Cerbo R, Fazzi E. Two-year infant neurodevelopmental outcome after single or multiple antenatal courses of corticosteroids to prevent complications of prematurity. Am J ObstetGynecol. 2004 Jul; 191 (1): 217-24.
20. Kiran PSS, Dutta S, Narang A, Bhansali A, Malhi P. Multiple Courses of Antenatal Steroids.Indian J Pediatr2007;74 (5):463-9.

21. Nicolau CM. et al. Desempenho motor em recém-nascidos pré-termo de alto risco. RevBrasCresc e Desenv Hum 2011; 21(2): 327-334.

22. Souza, T.G.,Stopíglia, M.S.,Baracat, E.C. Avaliação neurológica de recém-nascidos prétermo de muito baixo peso com displasia broncopulmonar. Rev Paul Pediatr.2009;27(1):21-7.

23. Singer LT, Siegel AC, Lewis B, Hawkins $S$, Yamashita T, Baley J. Preschool language outcomes of children with history of bronchopulmonary dysplasia and very low birth weight. J Dev BehavPediatr2001; 22(1): 19-26.

24. Katz-Salamon M, Gerner EM, Jonsson B, Lagercrantz, H. Early motor and mental development in very preterm infants with cronic lung disease. Arch Dis Child Fetal Neonatal 2000; 83(1): F1-F6.

25. Holcroft CJ, Blakemore KJ , Allen M, Graham EM. Association of prematurity and neonatal infection with neurologic morbidity in very low birth weight infants. ObstetGynecol 2003;101(6): 1249-53.

26. Moreira RS, Figueiredo EM. Instruments of assessment for first two years of life of infant; Journal of Human Growth and Development 2013; 23(2): 215-221

27. Silva NDSH et al. Instrumentos de avaliação do desenvolvimento infantil de recém-nascidos prematuros. Rev. Bras. Cresc. e Desenv. Hum. $2011 ; 21(1): 85-98$.

28. Herrero $D$ et al. Escalas de desenvolvimento motor em lactentes: Test of Infant Motor Performance e a Alberta Infant Motor Scale. Rev. Bras. Cresc. e Desenv. Hum. 2011; 21(1): 122132.

29. Mukerji A, Belik J Impact of birth-weight on adult minor illness. Journal of Human Growth and Development 2013; 23(1): 7-10.27.

30. Bellingham-Young DA, Adamson-Macedo EN. The impact of birthweight on adult minor illness: a study on a sub-clinical population.Journal of Human Growth and Development 2013; 23(1): 11-17.

\section{RESUMO}

Introdução: estudos sobre a associação entre o atraso no desenvolvimento motor e eventos observados durante o período neonatal são realizados após a alta hospitalar. Nesses casos, as associações encontradas podem sofrer a interferência de fatores ocorridos entre a alta da UTIN e a avaliação. Avaliar os recém-nascidos antes da alta hospitalar pode prevenir esses efeitos. Objetivo:verificar fatores associados ao desempenho motor de recém-nascidos e lactentes no momento da alta da Unidade de Terapia Intensiva Neonatal. Método: estudo de coorte prospectiva, de base populacional, analítico-descritivo de usuários do Sistema Único de Saúde. Foram avaliados 178 recém-nascidos e lactentes com o Test of Infant Motor Performance. Foi realizada análise de regressão logística binomial para verificar os fatores associados. Resultados: dos participantes, $58,4 \%$ eram prematuros, $56,2 \%$ nasceram com baixo peso e $59,0 \%$ eram do sexo masculino. As médias das características dos participantes foram: Peso ao nascimento $2304,3 \mathrm{~g}$, Idade gestacional 35,33 semanas. Ocorreu morbidade em $23,6 \%$ dos participantes e $34,8 \%$ apresentaram alteração no desempenho motor (64,7\% nos menores de $1501 \mathrm{~g}$ e $27,8 \%$ nos maiores de $1500 \mathrm{~g}$ ). Conclusões: Os resultados indicam que os fatores mais fortemente associados ao desempenho motor alterado foram ser prematuro, ter tido convulsão e ser do sexo feminino.

Palavras-chave: saúde da criança, desenvolvimento infantil, neonato, fatores de risco, saúde pública. 